\title{
ФОРМУВАННЯ ГОТОВНОСТІ МАЙБУТНІХ УЧИТЕЛІВ БІОЛОГІЇ ДО ПРОФЕСІЙНӦ̈ ДІЯЛЬНОСТІ ЗАСОБАМИ НАВЧАЛЬНО-НАУКОВИХ ЕКОЛОГІЧНИХ СТЕЖОК
}

\author{
Людмила Іванівна Довгопола \\ викладач кафедри теорії і методики професійної підготовки \\ ДВНЗ «Переяслав-Хмельницький державний \\ педагогічний університет імені Григорія Сковороди», \\ м. Переяслав-Хмельницький, Україна
}

DOI: https://doi.org/10.31435/rsglobal_ws/12072018/6000

\section{ARTICLE INFO}

Received: 16 May 2018

Accepted: 30 June 2018

Published: 12 July 2018

\section{KEYWORDS}

educational and scientific ecological trail,

students-biologists,

research work,

rare plants and animals,

zoocenosis,

phytocenosis,

interactive methods of training.

\begin{abstract}
The article deals with the experience of creation, didactic possibilities and peculiarities of the use of ecological trails. Their role in the training of future biology teachers is revealed. The definition of «comprehensive educational and scientific ecological path» is substantiated.

The characteristic and structure of the complex educational and scientific ecological trail «Outskirts of Pereiaslav region», created on the basis of the SHEI «Pereiaslav-Khmelnytskyi Hryhorii Skovoroda State Pedagogical University» was created and the possibilities of its use were analyzed. Some aspects of organizing research work for secondary and higher education students are covered. A set of tasks was proposed, which were carried out and carried out directly on each of the key sites of the path.

It was proved that the activity of secondary and higher education students, organized on the basis of the comprehensive educational and scientific ecological trail «Outskirts of Pereiaslavl region», promoted the expansion and deepening of biological knowledge, formed the ability to analyze and compare objects of wildlife, to find causal consequences, monitoring the environment, developing abilities for research and design activities, and raising cognitive activity.
\end{abstract}

Citation: Liudmyla Dovhopola (2018) Formation of Future Teachers of Biology to Professional Activity by Means of Educational Scientific Environmental Footwear. World Science. 7(35), Vol.1. doi: 10.31435/rsglobal_ws/12072018/6000

Copyright: (C) 2018 Liudmyla Dovhopola This is an open-access article distributed under the terms of the Creative Commons Attribution License (CC BY). The use, distribution or reproduction in other forums is permitted, provided the original author(s) or licensor are credited and that the original publication in this journal is cited, in accordance with accepted academic practice. No use, distribution or reproduction is permitted which does not comply with these terms.

Постановка проблеми. Реформування освітньої системи України спрямовано на ii інтеграцію до єдиного європейського простору вищої освіти, що передбачає формування нових фахових якостей у процесі підготовки майбутніх учителів. Освітній стандарт нового покоління детермінує упровадження у навчальний процес здобувачів вищої освіти таких педагогічних умов, методів, форм і технологій навчання, які б спонукали майбутніх учителів біології до продуктивної пошукової діяльності, що виявляє високий розвиваючий потенціал.

Вагомою педагогічною умовою, що пливає на процес формування готовності майбутніх учителів біології до професійної діяльності є організація безпосереднього контакту студентів із природнім середовищем, який забезпечується діяльністю здобувачів вищої освіти на навчальнонаукових екологічних стежках. 
Аналіз досліджень і публікацій. Вагомий внесок у методику розроблення та створення екологічних стежок зробили учені: Л. Бабюк [1], Я. Дідух, В. Єрмоленко, О. Крижанівська [7], С. Шпуляр [10] та ін.

Педагогічні дослідники Л. Антоновська [5], Н. Баюрко [2], В. Васін [4], Л. Вельчева [3], В. Вербицький [6], А. Ібатуллін [8], О. Комарова [9], О. Ходан [5], розглядають навчальну екологічну стежку як засіб професійної підготовки студентів у закладах освіти та формування екологічної та дослідницької грамотності в учнів.

Зважаючи на наявні наукові розвідки варто зазначити, що окремі аспекти такого роду досліджень до тепер є не розв'язаними.

Мета передбачає висвітлення особливостей застосування навчально-наукової екологічної стежки «Околицями Переяславщини» як засобу формування готовності майбутніх учителів біології до професійної діяльності у процесі практичної підготовки.

Виклад основного матеріалу. Екологічна стежка є природною матеріальною базою професійної підготовки студентів-біологів у процесі навчально-польової та педагогічної практики, навчально-виховна ефективність якої значно продуктивніша в порівнянні з типовими навчально-дослідними ділянками закладів освіти.

Так, В. Вербицький указує, що наявність навчальних екологічних стежок забезпечує умови для виконання системи завдань, які організовують та спрямовують діяльність учнів у природному оточенні. Вони здійснюються під час комплексних екологічних екскурсій, польових практикумів, які виступають новими міжпредметними формами організації навчальновиховного процесу [6].

Н. Баюрко в своєму дисертаційному дослідженні доводить, що безпосередня діяльність студентів-біологів на екологічних стежках і наявність у здобувачів вищої освіти практичних умінь і навичок до їх організації упливають на формування готовності майбутніх учителів біології до розвитку екологічної компетентності учнів основної школи [2].

На думку Я. Дідуха екологічна стежка $є$ унікальною та перспективною формою природоохоронної освіти. По-перше, навчання проходить не в процесі обов'язкового заходу, приуроченого до конкретної дати, місця чи часу, а при безпосередньому спілкуванні з дикою природою. По-друге, завдяки емоційному сприйняттю людиною природи, іїі впливові на всі органи чуття, цілеспрямовано формується позитивна емоційна сфера передусім у тих людей, які до цього зовсім не цікавилися природою і не мали особливого потягу до спілкування із нею [7].

Учені Я. Дідух, В. Срмоленко, О. Крижанівська та ін. розробили класифікацію екологічних стежок, яка $€$ найбільш поширеною та повною у сучасній науковій літературі. Вони виокремлюють такі їх різновиди:

1) спеціалізовані:

- наукові (виділяються за типовими й унікальними об'єктами досліджень із метою напрацювання методичних питань для науковців - ботаніків, зоологів, географів, археологів істориків тощо);

- навчальні (для проведення навчальних занять для дошкільних закладів, учнів загальноосвітніх навчальних закладів, студентів та слухачів); потенціал);

- рекреаційні (створюються на типових об’єктах природи, що мають високий рекреаційний

- лікувальоно-оздоровчі (охоплюють об' єкти природи, що виявляють особливе профілактичне й оздоровче значення, наприклад, поблизу санаторіїв; цей тип стежок може використовуватися із метою ознайомлення людей з умовами зростання та біологічними особливостями лікарських рослин);

- освітньо-ресурсні (створюються на типових об'єктах природи, мають високий еталонний природно-ресурсний потенціал, який використовується із метою підвищення рівня екологічної освіти природо користувачів).

2) комплексні (поєднують функції спеціалізованих екостежок);

3) туристичні екологічні маршрути [7].

Виходячи із поданої вище класифікації типів екологічних стежок, у дослідженні було доцільно організувати створення саме комплексної навчально-наукової екологічної стежки, що вбачає поєднання дидактичних завдань, які передбачають не лише формування екологічного світогляду а й: розширюють та поглиблюють знання, навички і вміння із природничих дисциплін здобувачів вищої і середньої освіти; включають вивчення природних об'єктів, які передбачені освітньо-професійною та шкільною програмами; максимально розкривають взаємозв'язки природних компонентів в екосистемах (поєднання елементів рослинного та тваринного світу між 
собою і довкіллям); передбачають організацію наукових досліджень живих природних об'єктів із метою практичного застосування методичних умінь.

Із метою цілеспрямованого формування у майбутніх учителів біології готовності до професійної діяльності у процесі практичної підготовки на базі ДВНЗ «ПереяславХмельницький державний педагогічний університет імені Григорія Сковороди» було створено комплексну навчально-наукову екологічну стежку «Околицями Переяславщини». Вона виступала постійною базою проведення:

- навчальних екскурсій (навчально-польові та педагогічні практики, екскурсії);

- навчальних занять (складання різноманітних проектів, у тому числі й природоохоронних, проведення уроків і практичних занять серед природи у відповідних пунктах стежки, засвоєння методики польових досліджень із метою вивчення природних живих об'єктів у різних середовищах їх існування);

- науково-дослідницької роботи (написання наукових робіт учнями-членами Малої академії наук України, кваліфікаційних робіт бакалавра або магістра, публікацій у фахових виданнях, матеріалах науково-практичних конференцій студентів, викладачів і вчителів, присвячених навчальній екологічній стежці та проведених на ній досліджень).

Так, Л. Вельчева вказує, що особливістю роботи на навчальній екологічній стежці $є$ поєднання теоретичних знань із особистою участю у різноманітних практичних справах захисту й поліпшення природи, а також у пропаганді знань про іiі охорону. Лише таке поєднання теоретичного пізнання і практичної діяльності формує основу освітньої компетентності учнів із біології та є дієвою формою професійної підготовки студентів-біологів [4].

Робота студентів та учнів на екологічній стежці передбачає розв'язання наступних задач: встановлення екологічних зв'язків між компонентами біогеоценозу в різних екосистемах; з'ясування впливу антропогенних чинників на екосистеми й окремі природні об'єкти; формування навичок екологічно доцільної поведінки в природі, розвиток екологічної відповідальності тощо.

Екологічна стежка виявляє важливий потенціал при проведенні просвітницької роботи серед широких верств населення шляхом організації екскурсій на екостежці 3 пропагандою природоохоронних заходів, інформування про види рослин і тварин, що трапляються на заданому маршруті та виданням буклету «Околицями Переяславщини».

О. Комарова висвітлює окремі аспекти організації дослідницької роботи учнів на екологічній стежці, наводить орієнтовну тематику дослідницьких робіт школярів на кожній із зупинок стежки, описує методику та подає результати роботи щодо визначення віталітету ценопопуляції сону лучного (Pulsatilla pratensis). Вона стверджує, що можливості для подальшої екологічно-просвітницької та дослідницької роботи на стежці важко переоцінити, особливо за умови залучення юннатів до пролонгованих екологічних досліджень [9].

Підсумовуючи вище сказане зазначимо, що навчально-наукова екологічна стежка передбачає триєдину мету: навчальну, розвиваючу та виховну.

Маршрут екологічної стежки прокладався таким чином, щоб охопити ділянки, що мають природничу цінність, які були б насичені максимальною кількістю видів рослин і тварин, що притаманні різним типам екотопів і були цікавими, доступними як із навчальної, так і практичної точки зору. Структура стежки включає шість ключових ділянок: №1 «Алея відділу Голонасінних», №2 «Заплавні луки р. Трубіж», №3 «р. Трубіж», №4 «Околиці Музею народної архітектури та побуту Середньої Наддніпрянщини», №5 «Антропогенний вплив на біогеоценози» та №6 «Лісове озеро».

«Алея відділу Голонасінних» презентує штучні насадження на території ДВНЗ «ПереяславХмельницький ДПУ імені Григорія Сковороди» представників відділу Голонасінних: сосна звичайна (Pinus sylvestris L.), ялівець звичайний (Juniperus communis L.), ялівець козацький (Juniperus sabina L.), широкогілочник східний або туя східна (Platycladus orientalis L.), туя західна (Thuja occidentalis L.) має садові форми «Aurescens», «Columna», ялина звичайна або європейська (Picea abies (L.) Karsten, або Picea excelsa Link.) та iï садові форми «Konca», «Aurea Magnifica», ялина колюча (Picea pungens L.) та iï садові форми «Koster», «Ноopsii», «Glauca», ялиця одноколірна (Abies concolor L.) та їі садові форми «Argentea», «Compacta» та ін. Дана ключова ділянка також включена до навчальної екологічної стежки, що розроблена вчителем біології загальноосвітнього навчального закладу №4 м. ПереяславаХмельницького В. Гайовою. У рамках педагогічної практики з біології у школі, здобувачі вищої освіти провели навчальну екскурсію учням 6-го класу на тему «Різноманітність рослин», використовуючи «Алею відділу Голонасінних». Студенти-практиканти застосовували інтерактивні методи навчання: «Мозковий штурм», «Мікрофон», «Коло ідей» та ін. Школярам були запропоновані різні проблемні 
запитання для групового обговорення із метою узагальнення вивченого матеріалу: «Як на вашу думку, чому Голонасінні віднесено до окремого відділу?», «У чому відмінність між хвойними і листяними деревами?», «Дуже часто в травні-червні можна почути вислів «сосна цвіте». Чи не $є$ це біологічною помилкою?» («Мозковий штурм»); «Шишка це -..», «Я дізнався про..», «Хвоя це -..», «Фітонциди це -..» («Мікрофон»). Було запропоновано учням, власноруч, створити колекцію шишок хвойних, як підсумок, проведено конкурс «Найкраща колекція Голонасінних».

Дана ключова ділянка активно використовується у процесі проведення студентам-біологам практичних і лабораторних занять 3 дисциплін: «Ботаніка. Анатомія, морфологія, фітоценологія рослин» (1-ий курс), «Ботаніка. Систематика та філогенія рослин» (2-ий курс), «Основи дендрології, квітникарства та фітодизайну» (3-ій курс). Завдання, які ставилися перед майбутніми вчителями біології на даній ділянці: здійснити морфологічний аналіз одного з виду хвойних рослин, вивчити розміщення чоловічих і жіночих шишок на прикладі сосни звичайної (P. sylvestris), виокремити характерні діагностичні ознаки притаманні представникам відділу Голонасінних тощо.

«Околиці Музею народної архітектури та побуту Середньої Наддніпрянщини» - дана ключова ділянка представлена степовими (схил) та заплавними луками (заплава р. Попівка).

Із метою з'ясування стану та динаміки популяцій рідкісних видів рослин природної флори, в рамках дослідницького проекту «Поширення та стан ценопопуляцій рідкісних видів рослин Переяславщини» 3 навчальної дисципліни «Ботаніка. Систематика та філогенія рослин», студентами закладено на даній території моніторингові облікові ділянки 3 астрагалом шерстистоквітковим (Astragalus dasyanthus Pall.) та пальчатокорінником Фукса (Dactylorhiza fuchsia (Druce) Soo), які включені до Європейського червоного списку та третього видання Червоної книги України 2003 р. У процесі дослідження околиць Переяславщини студенти складають списки рідкісних видів рослин, закартовують місця поширення, фотографують, описують, виділяючи при цьому їх екологічні особливості існування, визначають ступінь антропогенного впливу на них і рекомендують шляхи їх охорони.

Ключова ділянка «Антропогенний вплив на біогеоценози» являє собою закинутий кар'єр із добування піску. На даний момент це сміттєзвалище, де студенти й школярі мають змогу вивчати та досліджувати антропогенний флористичний комплекс, який складають: амброзія полинолиста (Ambrosia artemisiifolia L.), чорнощир нетреболистий (Iva xanthiifolia Nutt.), енотера червоностеблова (Oenothera rubricaulis Klebahn.), блошинець канадський (Соnуza canadensis (L.) Cronq.), золотушник канадський (Solidago canadensis L.), лобода біла (Chenopodium album L.) та ін. На екотопах, які постійно знаходяться під постійним антропогенним навантаженням майбутні вчителі біології та учні спостерігають процес деградації природного рослинного покриву: на порушених ділянках швидко поширюються бур'яни, які невибагливі до умов зростання, мають високу насіннєву продуктивність та високо конкурентоздатні. Кар'єр є місцем, де здобувачі вищої та середньої освіти можуть спостерігати гніздування колоній ластівки берегової (Riparia riparia).

На ключовій ділянці «Лісове озеро» презентовано лісовий, прибережно-водний і водний фіто- та зооценози.

Серед водних тварин зустрічаються двостулкові - беззубка звичайна (Anodonta cygnea) та черевоногі (ставковики великий (Lymnaea stagnalis) і малий (Galba truncatula), котушка рогова (Planorbis corneus) молюски. Серед ракоподібних превалюють - річковий рак (Astacus astacus), дафнія прісноводна (Daphnia pulex), циклоп річковий (Cyclops strenuous), водяний віслюк (Asellus aquaticus) та ін. У водоймах трапляються: павук сріблянка (Argyroneta aquatica), клоп водомірка (Hydrometra gracilenta), жук плавунець (Macrodytes marginalis) та водолюб великий чорний (Hydrous piceus) та ін.

У прибережно-водному екотопі звичайними є черепаха болотяна (Emys orbicularis), яку включено до Бернської конвенції (додаток II) та вуж звичайний (Natrix natrix), жаба ставкова (Pelophylax lessonae) та озерна (P. ridibundus). Поширені такі види птахів: лелека білий (Ciconia Ciconia), крижень (Anas platyrhynchos), крячок чорний (Chlidonias niger) та ін.

Із метою формування готовності студентів-біологів до професійної діяльності у процесі практичної підготовки було створено комплекс завдань, які виконувалися і проводилися безпосередньо на навчально-науковій екологічній стежці «Околицями Переяславщини»:

- встановити видову різноманітність лікарських рослин заплавних лук, водної та прибережно-водної рослинності р. Трубіж і о. Лісове;

- організувати дискусію: «Механізм линяння річкового рака (A. astacus), його фізіологічне значення», «Лікувальні властивості звіробою звичайного (Hypericum perforatum L.). Ризики фітотерапії»; 
- організувати інтерактивну гру «Коло ідей». Обгрунтувати: чим пояснюється відсутність голови у двостулкових молюсків; як визначити вік сосни звичайної (P. sylvestris) без зрізу деревини тощо;

- спростувати або довести логічність твердження: «Хвощ польовий індикатор кислих грунтів», «М'якуни - індикатори чистоти водойм» тощо;

- запропонувати протокол проведення дослідження екологічних особливостей беззубки звичайної (A. cygnea);

- встановити чисельність популяції дафнії (Daphnia) у залежності від біологічного забруднення водойми. Порівняти одержані результати з р. Трубіж та о. Лісове;

- встановити видовий склад хребетних і безхребетних тварин - мешканців озера, прибереженої та лісової зон зазначених ключових ділянок;

- визначити рідкісні види рослин і тварин їх поширення та стан популяцій;

- встановити антропогенний вплив на фіто- та зооценози навчально-наукової екологічної стежки;

- встановити чисельність популяції жука-короїда (Scolytus mali) та іiї вплив на сосновий ліс. Запропонувати методи боротьби з шкідником лісу.

Висновки. Отже, діяльність здобувачів середньої та вищої освіти, організована на базі комплексної навчально-наукової екологічної стежки «Околицями Переяславщини», сприяла розширенню та поглибленню біологічних знань, формувала уміння аналізувати й порівнювати об'єкти живої природи, знаходити причино-наслідкові зв'язки, здійснювати моніторинг довкілля, розвивала здібності до науково-дослідницької та проектної діяльності, підвищувала пізнавальну активність.

Перспективи подальших наукових розвідок будуть спрямовані на пошук дієвих організаційно-педагогічних умов, методів, форм i технологій навчання, що сприятимуть зростанню рівня сформованості готовності у майбутніх учителів біології до професійної діяльності у процесі практичної підготовки.

\section{ЛІТЕРАТУРА}

1. Бабюк Л. М. Теоретико-методологічні засади наукового обгрунтування створення екологічних стежок. Природа Західного Полісся та прилеглих територій. 2010. № 7. С. 71-75.

2. Баюрко Н. Підготовка майбутніх учителів біології до розвитку екологічної компетентності учнів основної школи: монографія. Вінниця: ТОВ «Нілан ЛТД», 2017.- 256 с.

3. Вельчева Л. Г. Антоновська Л. В., Разнополов О. М., Ходан О. В. Екологічна стежка навчальнонаукового арборетуму. Постметодика. 2005. № 4-5(62-63). С. 19-22.

4. Вельчева Л. Г. Екологічна стежка навчально-наукового арборетуму. Агробіологічний комплекс як навчально-дослідницьке середовище. 2005. № 4-5. С. 19-22.

5. Вельчева Л. Г., Васін В. А. Навчальна екологічна стежка «Дивосвіт навколо нас» як засіб професійної підготовки студентів до викладання біології та екології у загальноосвітніх навчальних закладах. Вісник Національного мелітопольського держсавного педагогічного університету ім. Богдана Хмельницького. 2010. № 5. С. 35-42.

6. Вербицький В. В. Формування практичного розуму цілеспрямованого учня (з досвіду сталого розвитку позашкільної еколого-натуралістичної освіти). Київ: Деміур, 2002. 232 с.

7. Дідух Я. П., Єрмоленко В. М., Крижанівська О. Т., Попович С. Ю. та ін. Екологічна стежка (методика, організація, характеристика модельної стежки «Лісники»). Київ: Фітосоціоцентр, 2000. 88 с.

8. Ибатуллин А. А. Учебная экологическая тропа как средство развития продуктивной деятельности учащихся. Педагогическое образование в России: сб. науч. тр. 2011. № 2. С. 178-181.

9. Комарова О. Організація дослідницької роботи учнів на екологічній стежці. Біологія $і$ хімія в школі. 2011. № 6. C. 7-10.

10. Шпуляр С. Б. Методика створення екологічної стежки. Івано-Франківськ: Вид-во «Екологонатуралістичний центр», 2011.27 с. 